\title{
Karakterisasi Molekuler Bakteri Probiotik Ikan Kerapu Bebek Berbasis Teknik 16S Ribosomal DNA
}

\author{
Feliatra, Nursyirwani, \& Wahyudi Andrito \\ Laboratorium Mikrobiologi, Fakultas Perikanan dan Ilmu Kelautan, Universitas Riau, Pekanbaru 28293 \\ Email: feliatra@yahoo.com
}

Diterima 13-05-2007 Disetujui 02-09-2007

\begin{abstract}
The aim of research was to find the molecular characteristics of probiotic bacteria in the digestive tract of grouper fish (Chromileptes altivelis) based on 16S ribosomal DNA technique. The bacteria were isolated from stomach and intestine of the fish and were analized in the Marine Microbiology Laboratory of fishery and marine Science Faculty of Riau University. The bacterial DNA were isolated by using a PCR (polymerase Chain Reaction) and was conducted in the biotechnology laboratory of Diponegoro University, Semarang. The purified DNA was sequenced in the BPPT Tangerang. Result shown that 6 bacterial species may be potential as probiotic. There were Bacillus velesensis strain CR-11, Vibio alginolyticus A3G-2, Bacillus cereus site2S, uncultured bacterium clone BB3S16S-17, Bacillus subtillus strain CICC10066, and Bacillus flexus strain LF-3. these bacteria grow well at pH 2 and this indicated one of probiotic bacteria characteristics.
\end{abstract}

Keywords: bacteria, DNA, fish, probiotic

\section{PENDAHULUAN}

Pesatnya perkembangan usaha pembesaran ikan kerapu bebek tidak didukung oleh ketersedian pakan, sehingga di beberapa daerah yang potensial untuk pengembangan usaha pembesaran sering terjadi kendala kekurangan pakan. Dalam usaha pembesaran ikan, pakan merupakan faktor utama yang harus terus tersedia dan menjadi salah satu faktor keberhasilan dalam budidaya ikan. Ketersediaan pakan yang berkualitas dengan memperhatikan keseimbangan gizi dan jumlah yang sesuai dengan kebutuhan, tepat waktu dan berkelanjutan membutuhkan biaya produksi yang cukup besar (Akbar 2005).

Sebagai pengganti antibiotik, nutritionist merekomendasikan peternak menggunakan probiotik sebagai bahan aditif. Probiotik merupakan mikroorganisme yang dapat meningkatkan pertumbuhan dan efisiensi pakan ternak tanpa mengakibatkan terjadinya proses penyerapan komponen probiotik dalam tubuh ternak, sehingga tidak terdapat residu dan tidak terjadinya mutasi pada ternak. Selanjutnya ditambahkan bahwa bakteri probiotik dapat memberikan keutungan pada kesehatan manusia dan ternak seperti meningkatkan pertumbuhan, meningkatkan produksi susu, dan meningkatkan sistem kekebalan tubuh.
Sekuens 16S rDNA probiotik dalam akuakultur masih merupakan konsep baru pada bidang perikanan, beberapa penelitian sejauh ini masih terfokus pada masalah pengontrolan terhadap penyakit dan keuntungan dalam perbaikan pertumbuhan dari penambahan probiotik. Bakteri probiotik dapat bertahan hidup dalam saluran pencernaan setelah dikonsumsi. Bakteri ini tahan terhadap lisozim (zat pemecah dinding sel bakteri) dan asam empedu sehingga sampai ke usus dalam keadaan hidup, mampu melekat pada sel epithelia, dan menjaga keharmonisan komposisi bakteri saluran pencernaan (Feliatra 2002). Selanjutnya bakteri ini mampu mengatasi intoleransi terhadap laktosa, mencegah diare, sembelit, kanker, hipertensi, menurunkan kolesterol, menormalkan komposisi bakteri saluran pencernaan setelah pengobatan antibiotik, serta meningkatkan sistem kekebalan tubuh (Waspodo 2002). Gen 16S rDNA merupakan komponen penting dalam sel dan sangat menguntungkan di dalam analisis filogenik, karena terdiri dari daerah-daerah yang dikonservasi sehingga mutasi akan terbatas, studi sistematika bakteri pada tingkat famili, genus, spesies, ataupun subspesies (Chen et al, 2000).

Brock dan Madigan, (1991), menyatakan bahwa 16S rDNA sangat mudah penanganannya dari pada 235 rDNA, maka 16S rDNA lebih sering digunakan untuk 
melihat perkembangan filogenetik prokariota dan beberapa pada eukariota. 16S rDNA terdapat pada semua prokariota dan memiliki bagian atau sekuen konservatif dan sekuen lainnya sangat bervariasi. Sabdono, (2001), menambahkan bahwa sekuen nukleotida 16S rDNA tidak hanya memudahkan pemahaman yang lebih baik pada filogenetik mikroba. Namun juga memudahkan identifikasi bakteri dari sampel lingkungan.

Penerapan filogenetik molekuler pada ekologi mikroba menunjukkan adanya diversitas prokariotik yang terjadi secara alami. Lebih dari 16.000 sekuen gen $16 S$ rDNA dari berbagai spesies bakteri telah disimpan dalam Gen Bank. Gen 16S rDNA mempunyai daerah sekuen yang dikonversi, sihingga dapat digunakan untuk menduga hubungan kekerabatan secara alami antar spesies yang mempunyai kekerabatan jauh serta dapat digunakan untuk membedakan spesies yang mempunyai kekerabatan dekat dari berbagai daerah (Rhodest et al, 1998). Tujuan penelitian ditemukannya isolat murni bakteri probiotik yang berasal dari saluran pencernaan ikan kerapu bebek asli Indonesia. kedepannya dapat dikembangkan untuk akuakultur di Indonesia, khususnya formulasi pada pakan ikan dengan penambahan bakteri probiotik asli Indonesia sehingga bisa dikembangkan oleh industri pakan sebagai pakan yang berkualitas tinggi.

\section{BAHAN DAN METODA}

Penelitian ini dilaksanakan pada bulan September 2006 sampai Desember 2006. Sampel ikan kerapu bebek (Chromileptes altivelis) diperoleh Balai Budidaya ikan Batam. Isolasi dan identifikasi bakteri probiotik pada saluran pencernaan ikan Kerapu Bebek dilakukan di Laboratorium Mikrobiologi Fakultas Perikanan dan Ilmu Kelautan Universitas Riau, sedangkan untuk PCR (Polymerae Chain Reaction) dilakukan di Laboratorium Bioteknologi Universitas Diponegoro Semarang. Hasil purifikasi DNA dikirim ke Balai Pengkajian Pengembangan Teknologi (BPPT) Tangerang Jakarta untuk disekuensing.

Bahan-bahan yang digunakan antara lain: media agar non selektif TSA (Tryptone Soya Agar), kulturbakteri, aquabides, primer $27 \mathrm{~F}$ (AGAGTTTGATCMTGGCTCAG) dan 1492 R (TACGGYTACCTTGTTACGACTT), megamix royal (MMR), DNA purification kit, isopropanol, loading buffer,
DNA marker, buffer TAE 1X, agarose gel, ethanol, ethidium bromide.

Metode yang digunakan adalah metode survei, dengan mengamati sel bakteri probiotik pada saluran pencernaan ikan kerapu bebek. Ikan kerapu bebek dibedah secara aseptis untuk diambil organ pencernaannya (lambung dan usus) digerus dan diencerkan dalam larutan pengencer sampai taraf pengenceran yang diinginkan lalu dimasukkan ke dalam larutan fisiologis $(\mathrm{NaCl} 0,9 \%)$ pada $\mathrm{pH}$ 2, dengan tujuan hanya bakteri probiotik yang dapat tumbuh dan berkembang pada $\mathrm{pH}$ tersebut. Penyimpanan koloni bakteri dilakukan pada suhu $40^{\circ} \mathrm{C}$ dan siap untuk digunakan pada pengujian selanjutnya setelah diperoleh isoalt murni dilakukan analisis lanjutan yaitu dengan Prosedur yang dilakukan adalah Freez and Thaw, Polymerase Chain Reaction, Elektroforesis, dan Pengamatan Hasil PCR Pada Gel Agarose, Purifikasi Gel Elektroforesis, Sequensing DNA, Analisis Sequen DNA Isolat Bakteri (Radjasa 2006)

\section{HASIL DAN PEMBAHASAN}

Berdasarkan hasil penelitian yang dilakukan,diperoleh bahwa bakteri yang diisolasi dari usus dan lambung ikan kerapu bebek dapat tumbuh dan berkembang pada media kultur TSA dengan $\mathrm{pH} 2$, yang merupakan indikator utama bakteri probiotik. Koloni bakteri yang tumbuh pada media terdapat dalam berbagai macam bentuk, warna, tepian, ukuran, dan permukaan koloni (elevasi) yang berbeda. Dari hasil pengamatan morfologi ditemukan 6 isolat bakteri pada saluran pencernaan ikan kerapu macan yaitu $\mathrm{BPa}$, $\mathrm{BPb}, \mathrm{BPc}, \mathrm{BPd}, \mathrm{BPe}$, dan $\mathrm{BPf}$. Masing-masing isolat memiliki morfologi yang berbeda satu sama lain. Hasil amplifikasi DNA PCR universal dari ke-6 isolat bakteri dapat dilihat pada gambar 1. Gambar 1 menunjukkan bahwa semua isolat menghasilkan pita tunggal dengan ukuran sekitar 1500 bp (base pair) sesuai dengan pembandingan menggunakan marker DNA. Besarnya ukuran ini sesuai dengan ukuran yang diharapkan dari gen-gen 16S rDNA bakteri yaitu 1500-1600 bp.

Sekuensing DNA Isolat Bakteri. Hasil sekuensing 16S rDNA dari masing-masing isolat bakteri dapat dilihat pada Tabel 1.

Analisis Sekuen DNA Isolat Bakteri. Hasil penelusuran sekuen masing-masing isolat bakteri dengan sistem BLAST dapat dilihat pada Tabel 2. 
Bakteri probiotik adalah bakteri hidup yang diberikan sebagai suplemen makanan yang mempunyai pengaruh yang menguntungkan pada kesehatan baik pada manusia maupun hewan, dengan memperbaiki keseimbangan mikroflora intestinal. Bakteri-bakteri non patogen (probiotik) yang berdomisili di usus terutama usus besar dan mengadakan kolonisasi yang membentuk mikroekosistem yang bermanfaat untuk kesehatan dalam aspek ketahanan infeksi, aspek metabolik dan aspek imunologis.
Dari identifikasi molekuler, bakteri yang terdapat pada saluran pencernaan kerapu bebek didominasi oleh bakteri dari genus Bacillus dan diikuti oleh Vibrio. Bakteri dari genus Bacillus merupakan bakteri probiotik yang sudah banyak dikomersilkan. Irianto (2003), menyatakan bahwa Bacillus sp. merupakan bakteri probiotik komersil yang dapat ditebar pada kolam atau tambak. Bakteri ini dapat menghambat pertumbuhan bakteri patogen seperti bakteri Vibrio harveyi yang berada di perairan. Selanjutnya dikatakan bahwa tidak

Tabel 1. Hasil sekuensing gen $16 \mathrm{~S}$ rDNA dari isolat bakteri

Isolat Sekuen gen 16S rDNA

BPa GCTTTGGACCCCAAAAAGGGGGTGGAAGAAACCTCGCCTGGAAGACTCGGGGTAACTCCGGGAAACCGGGGCTAATACC GGATGGTTGTTTGAACCGCATGGTTCAGACATAAAAGGTGGCTTCGGCTACCACTTACAGATGGACCCGCGGCGCATTAG CTAGTTGGTGAGGTAACGGCTCACCAAGGCAACGATGCGTAGCCGACCTGAGAGGGTGATCGGCCACACTGGGACTGAG ACACGGCCCAGACTCCTACGGGAGGCAGCAGTAGGGAATCTTCCGCAATGGACGAAAGTCTGACGGAGCAACGCCGCGT GAGTGATGAAGGTTTTCGGATCGTAAAGCTCTGTTGTTAGGGAAGAACAAGTGCCGTTCAAATAGGGCGGCACCTTGACG GTACCTAACCAGAAAGCCACGGCTAACTACGTGCCAGCAGCCGCGGTAATACGTAGGTGGCAAGCGTTGTCCGGAATTAT TGGGCGTAAAGGGCTCGCAGGCGGTTTCTTAAGTCTGATGTGAAAGCCCCCGGCTCAACCGGGGAGGGTCATTGGAAAC TGGGGAACTTGAGTGCAGAAGAGGAGAGTGGAATTCCACGTGTAGCGGTGAAAATGCGTAGAGATGTGGAGGAACACCA GTGGCGAAGGCGACTCTCTGGTCTGTAACTGACGCTGAGGAGACGAAAAGCGTGGGGGAGCGAACAAGGTTTTGATACC CCGGGTGGT

BPb ACTGCCCTGTTCCGAGGCAGGCGGACGGGTGGAGTAATGGCCTAGGAAATTGCCCTGATGTGGGGGATAACCATTGGAA ACGATGGCTAATACCGCATAATGCCTACGGGCCAAAGAGGGGGACCTTCGGGCCTCTCGCGTCAGGATATGCCTAGGTG GGATTAGCTAGTTGGTGAGGTAATGGCTCACCAAGGCGACGATCCCTAGCTGGTCTGAGAGGATGATCAGCCACACTGGA ACTGAGACACGGTCCAGACTCCTACGGGAGGCAGCAGTGGGGAATATTGCACAATGGGCGCAAGCCTGATGCAGCCATG CCGCGTGTGTGAAGAAGGCCTTCGGGTTGTAAAGCACTTTCAGTCGTGAGGAAGGTGGTAGAGTTAATAGCTCCATTATTT GACGTTAGCGACAGAAGAAGCACCGGCTAACTCCGTGCCAGCAGCCGCGGTAATACGGAGGGTGCGAGCGTTAATCGGA ATTACTGGGCGTAAAGCGCATGCAGGTGGTTTGTTAAGTTAA

BPc CATTTTACGGGGGGGGCCCGATCCACGCACGTCGAGCGAATGGATAAGAGCTTGGTCTTATGAAGTTAGGGGCCTTACG GGAGAGTTAACGTGGGTAACCTGCCCATAAGACTGGGATAACTCCGGGAAACCGGGGCTAATACCGGATAACATTTTGAA CCGCATGGTTCGAAATTGAAAGGCGGCTTCGGCTGTCACTTATGGATGGACCCGCGTCGCATTAGCTAGTTGGTGAGGTA ACGGCTCACCAAGGCAACGATGCGTAGCCGACCTGAGAGGGTGATCGGCCACACTGGGACTGAGACACGGCCCAGACT CCTACGGGAGGCAGCAGTAGGGAATCTTCCGCAATGGACGAAAGTCTGACGGAGCAACGCCGCGTGAGTGATGAAGGCT TTCGGGTCGTAAAACTCTGTTGTTAGGGAAGAACAAGTGCTAGTTGAATAAGCTGGCACCTTGACGGTACCTAACCAGAAA GCCACGGCTAACTACGTGCCAGCAGCCGCGGTAATACGTAGGTGGCAAGCGTTATCCGGAATTATTGGGCGTAAAGCGC GCGCAGGTGGTTTCTTAAGTCTGATGTGAAAGCCCACGGCTCAACCGTGGAGGGTCATTGGAAACTGGGAGACTTGAGTG CAGAAGAGGAAAGTGGAATTCCATGTGAGCGGTGAAATGCGTAGAGATATGGAGGAACA

BPd ACAACCTTACGCCCAACGTCCGGAGCGGGAAACAAGTGATCTGAACCTTCGGGGAACGATAACGGCGTCGAGCGGCGGA CGGGTGAGTAATGCCTAGGAAATTGCCCTGATGTGGGGGATAACCATTGGAAACGATGGCTAATACCGCATAATGCCTAC GGGCCAAAGAGGGGGACCTTCGGGCCTCTCGCGTCAGGATATGCCTAGGTGGGATTAGCTAGTTGGTGAGGTAATGGCT CACCAAGGCGACGATCCCTAGCTGGTCTGAGAGGATGATCAGCCACACTGGAACTGAGACACGGTCCAGACTCCTACGG GAGGCAGCAGTGGGGAATATTGCACAATGGGCGCAAGCCTGATGCAGCCATGCCGCGTGTGTGAAGAAGGCCTTCGGGT TGTAAAGCACTTTCAGTCGTGAGGAAGGTGGTGGAGTTAATAGCTCTATTATTTGACGTTAGCGACAGAAGAAGCACCGGC TAACTCCGTGCCAGCAGCCGCGGTAATACGGAGGGTGCGAGCGTTAATCGGAATTACTGGGCGTAAAGCGCATGCAGGT GGTTTGTTAAGTCAGATGTGAAAGCCCGGGGCTCAACCTCGGAATAGCATTTGAAACTGGCAGACTAGAGTACTGTAGAG GGGGGTAGAATTTCAGGTGTAGCGGTGAAATGCGTATAGATCTTCAGGGAATACTGGTGG

BPe TTCCGGAAGCCGGACACGATGTGGAGCTTGCTCCCTGATGTTAGCGGCGGACGGGTGAGTAACACGTGGGTAACCTGCC TGTAAGACTGGGATAACTCCGGGAAACCGGGGCTAATACCGGATGGTTGTTTGAACCGCATGGTTCAAACATAAAAGGGG GCTTCGGCTACCACTTACGGATGGACCCGCGGCGCATTAGCTAGTTGGTGAGGTAACGGCTCACCAAGGCAACGATGCG TAGCCGACCTGAGAGGGTGATCGGCCACACTGGGACTGAGACACGGCCCAGACTCCTACGGGAGGCAGCAGTAGGGAA TCTTCCGCAATGGACGAAAGTCTGACGGAGCAACGCCGCGTGAGTGATGAAGGTTTTCGGATCGTAAAGCTCTGTTGTTA GGGAAGGACAAGTACCGTTCGAATAGGGCGGTTCCTTGACGGTACCTGACCAGAAAGCCACGGCTAACTACGTGCCAGC TACCGCGGTAATACGTAGGTGGCAAGCGTTGTCCGGAATTATTGGGCGTAAAGGGCTCGCAGGCGGTTTCTTAAGTCTGA TGTGAAAGCCCCCGGCTCACCGGGGAGGGTCATTGGAAACTGGGGGAACTTGTGTGCAGAAGAGGAGAGTGGGAATTCC TCCG

BPf GCAATTGGGAGCATCGATGTCCGCGCGACGGAGGAGCAACACGGGGGCAACCGGCCTGTTAAACGGGGAGAACTCCGG GAAACCGGAGGTAATCCCGGATAACATTTTCTCTTGGATAACAGAAAATTGAAGGATGGCTTCGGCTATCACTTACAGATG GGTCCCCGGGGCATTATCTCGTTGGGGAGGTAACGGGTCTCCAAAAGGACAATGCATAGCCGACGTGAGAGGGGGAGCT CCCACACTGTGACTCAGACACGCCCCACACTCCTCCACGAGGCACCACTAGGGAATCTTCCGCAATGGACGAAAGTCTGA CATACCACCGCCCCGTGTGTGATAAAGGCTTTCGGGGCGTAAAACTCTGTTGTTAGCGAAGAACAGGTACAAGAGTTACT GCTTGTACCTTGACGGTACCTAACCAGAAAGCCACGGCTAACTACGTGCCAGCAGCCGCGGTAATACGTAGGTGGCAAGC GTTATCCTGAATTATTGGGGGTAAAGCGCGCGTAGGCGGTTTCT 


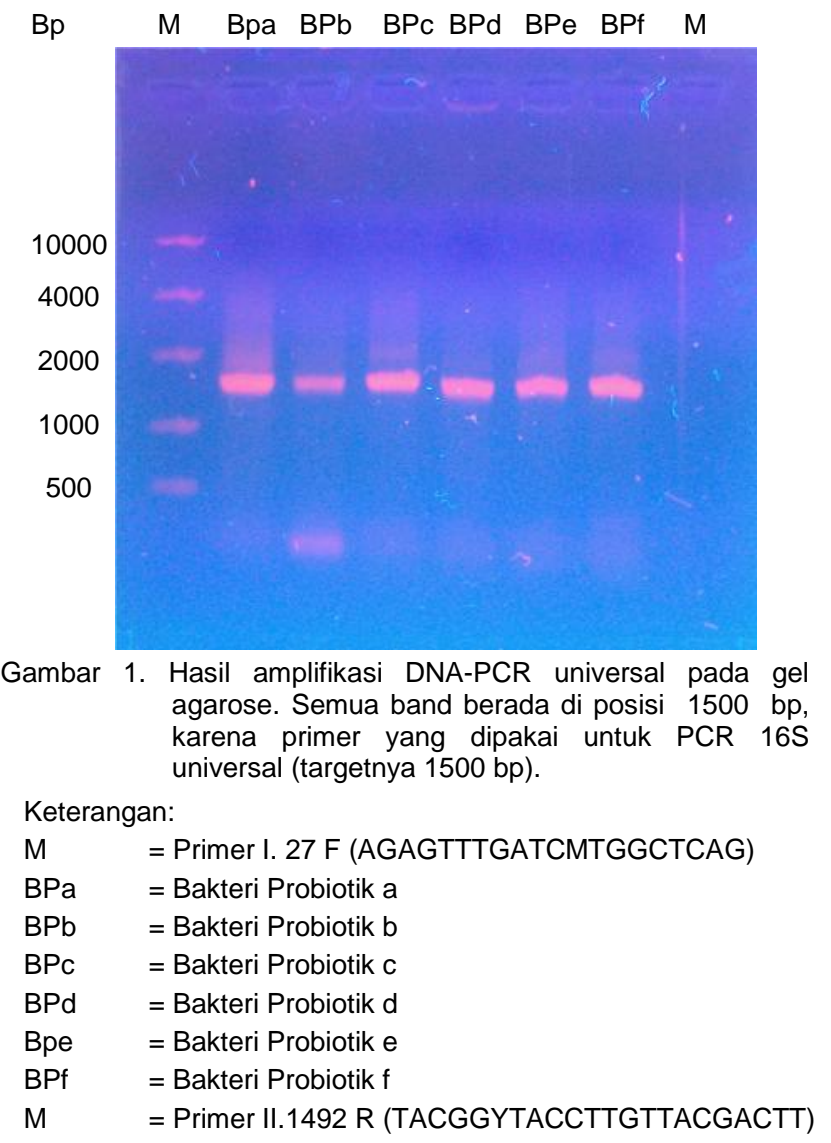

semua dari genus vibrio merupakan bakteri patogen, seperti Vibrio alginolyticus merupakan bakteri probiotik yang banyak terdapat pada air laut. Bakteri ini dapat hidup pada saluran pencernaan ikan selama 21 hari pada suhu $15^{\circ} \mathrm{C}$. Bakteri ini juga dapat menghambat pertumbuhan bakteri patogen seperti Aeromonas salmonicida, Vibrio ordalii dan Vibrio anguillarum.

Dari tabel homologi sekuen $16 \mathrm{~S}$ rDNA dari masingmasing isolat bakteri dengan sekuen $16 \mathrm{~S}$ rDNA dari data base bank diketahui bahwa tidak ada sekuen 16 $\mathrm{S}$ rDNA isolat bakteri yang indentik. Hagstrom et al, (2000), menyatakan bahwa isolat yang mempunyai persamaan sekuen 16 S rDNA lebih dari $97 \%$ dapat mewakili spesies yang sama. Sedangkan persamaan sekuen antara $93-97 \%$ dapat mewakili identitas pada tingkat genus tetapi berbeda pada tingkat spesies.

Dari pernyataan tersebut dapat dikatakan bahwa isolat $\mathrm{BPa}$ mempunyai kekerabatan dengan Bacillus velesensis strain CR-11 pada tingkat spesies karena mempunyai persamaan sikuen $99 \%$ sebanyak 638 spesies dari 642 spesies yang telah ditemukan. Isolat $\mathrm{BPb}$ mempunyai tingkat kekerabatan spesies dengan Vibrio alginolyticus A3G-2 dengan persamaan sekuen $98 \%$ sebanyak 643 spesies dari 652 spesies yang telah
Tabel 2. Hasil penelusuran sekuen 16S rDNA isolat bakteri dengan sistem BLAST

\begin{tabular}{clcc}
\hline Isolat & \multicolumn{1}{c}{ Hasil Sekuensing } & $\begin{array}{c}\text { Homologi } \\
(\%)\end{array}$ & No Akses \\
\hline $\mathrm{BPa}$ & $\begin{array}{l}\text { Bacillus velesensis } \\
\text { strain CR-11 }\end{array}$ & 99 & AY605932 \\
$\mathrm{BPb}$ & $\begin{array}{l}\text { Vibrio alginolyticus } \\
\text { A3G-2 }\end{array}$ & 98 & DQ995519 \\
$\mathrm{BPc}$ & $\begin{array}{l}\text { Bacillus cereus site2S } \\
\text { Uncultured bacterium } \\
\mathrm{BPd}\end{array}$ & 99 & DQ420176 \\
$\mathrm{BPe}$ & $\begin{array}{l}\text { Clone BB3S16S-17 } \\
\text { Bacillus subtilis strain }\end{array}$ & 98 & EF089472 \\
$\mathrm{BPf}$ & $\begin{array}{l}\text { CICC10066 } \\
\text { Bacillus flexus strain } \\
\text { LF-3 }\end{array}$ & 98 & EF127831 \\
\hline
\end{tabular}

ditemukan, isolat BPc mempunyai tingkat kekerabatan spesies dengan Bacillus cereus site2S dengan persamaan sekuen $98 \%$ sebanyak 658 spesies dari 668 spesies yang telah ditemukan, isolat $\mathrm{BPd}$ mempunyai tingkat kekerabatan spesies dengan Uncultured bacterium clone BB3S16S-17 dengan persamaan sekuen $99 \%$ sebanyak 636 spesies dari 641 spesies yang telah ditemukan, isolat $\mathrm{BPe}$ mempunyai tingkat kekerabatan spesies dengan Bacillus subtilis strain CICC10066 dengan persamaan sekuen $98 \%$ sebanyak 595 spesies dari 605 spesies yang telah ditemukan, dan isolat BPf mempunyai tingkat kekerabatan spesies dengan Bacillus flexus strain LF-3 dengan persamaan sekuen $98 \%$ sebanyak 432 spesies dari 485 spesies yang telah ditemukan.

Hasil analisis fragmen DNA hasil amplifikasi PCR menunjukkan bahwa terdapat empat isolat yang mempunyai kekerabatan dekat, yaitu isolat $\mathrm{BPa}$, isolat $\mathrm{BPc}$, isolat $\mathrm{BPe}$, dan isolat $\mathrm{BPf}$ yang menunjukkan persamaan pada tingkat genus yaitu Bacillus. Sedangkan isolat $\mathrm{BPb}$ menunjukkan persamaan pada tingkat genus Vibrio.

Setiap spesies bakteri memiliki ciri-ciri molekuler yang dapat membedakannya dari satu spesies dengan spesies yang lain dalam satu genus. Bakteri Bacillus velesensis strain CR-11 memiliki ciri-ciri molekuler yaitu terdiri atas 721 pasang basa nitrogen, bakteri Vibrio alginolyticus A3G-2 terdiri atas 514 pasang basa nitrogen, bakteri Bacillus cereus site2S terdiri atas 694 pasang basa nitrogen, Uncultured bacterium clone BB3S16S-17 terdiri atas 694 pasang basa nitrogen, bakteri Bacillus subtilis strain CICC10066 terdiri atas 631 pasang basa nitrogen, dan bakteri Bacillus flexus strain LF-3 terdiri dari 514 pasang basa nitrogen. Ini 
dapat dilihat dari elektroperogram hasil sekuen mesin squencer menggunakan Bigdye V. 3.1.

\section{KESIMPULAN}

Hasil penelitian menunjukkan bahwa pada ikan kerapu bebek ditemukan 6 spesies bakteri yang berpotensi sebagai probiotik, yaitu Bacillus velesensis strain CR-11, Vibrio alginolyticus A3G-2, Bacillus cereus site2S, Uncultured bacterium clone BB3S16S-17, Bacillus subtilis strain CICC10066, dan Bacillus flexus strain LF-3. Keenam bakteri ini berpotensi sebagai probiotik karena memilik ketahanan pada $\mathrm{pH} 2$ yang merupakan indikator utama sebagai bakteri probiotik.

\section{UCAPAN TERIMA KASIH}

Pengelola hibah A2 Program Studi IImu Kelautan Fakultas Perikanan dan IImu Kelautan UNRI yang sudah mendanai penelitian ini, Dr. Ocki Karna Radjasa dari Universitas Diponegoro Semarang yang sudah banyak membantu, BPPT Serpong Tangkerang, dan semua pihak yang sudah membantu terlaksananya penelitian ini.

\section{DAFTAR PUSTAKA}

Akbar, S. 2005. Meramu Pakan Ikan Kerapu: Bebek, Lumpur, Macan, Malabar. Cetakan ke-3. Jakarta: Penebar Swadaya. Altsuchul, S.F., Madden, T.L., Schaffer, A. A., Zhang, J., Zhang, Z., Miller, W. \& Lipman, D. J. 1997. Gapped BLAST and PSI-BLAST: a New generation of protein database search programs. Nucleic Acid Res. 25: 3389-3402.

Brock, T.D. \& Madigan, M.T. 1991. Biology of Microorganisms. New Jersey: Prentice Hall Englewood Cliffs.

Chen, J., Banks, D., Jarret, L., Chang, C.J. \& Smith B.J. 2000. Use of $16 \mathrm{~S}$ rDNA sequences as signature characters to identify Xylella fastidiosa. Curr. Microbiol. 40: 29-33.

Felliatra. 2002. Implementasi dan pengembangan bioteknologi kelautan dalam upaya optimalisasi pemanfaatan laut Indonesia. Pengukuhan Jabatan Guru Besar pada Fakultas Perikanan dan IImu Kelautan Universitas Riau, 5 November 2002. Pekanbaru: Universitas Riau. Tidak diterbitkan.

Griffitns, A.J.F., Miller, J.H., Suzuki, D.T., Lewontin, R.C. \& Gelbarts, W.M. 1996. An Introduction to Genetic Analisys. New York: W. H. Freeman and Co.

Hangstrom, A., Pinhassi, J., \& Zweifel, U.I. 2000. Biogeographical diversity among marine bacterioplankton. Aquatic microbial Ecology. 21: 231-244

Irianto, A. 2003. Probiotik Akuakultur. Yogyakarta: Gadjah Mada University press.

Radjasa, K.O. 2006. Rapid grouping Of marine psychrotrophic bacteria using restriction fragment length polymorphism analysis of PCR-amplified 16S. http://www.karna radjasa.com. (15 September 2007)

Rhodes, A.N., Urbance, J.W., Youga, H., Corlew-Neuman, H., Reddy, C.A., Klug, M.J., Tiedje, J.M. \& Fisher, D.C. 1998. Identification of bacterial isolates obtained from intestinal contents associated with 12.000 years old mastodon remain. Appl. Environ. Microbiol. 64: 651-658.

Sabdono, A. 2001. Identifikasi dan Analisis Genetik Bakteri Karang Pendegradasi Senyawa Herbisida 2,4Diklorofenoksi Asetat di Laut Jawa. Yogyakarta: Universitas Gajah Mada Press.

Waspodo, I.S. 2001. Efek probiotik, prebiotik, dan sinbiotik bagi kesehatan. http://www.kompas.com/kompascetak/0109/30/ iptek/efek22.htm. (15 September 2007) 